\title{
Banking competition in the Brazilian economy
}

Competição bancária na economia brasileira

\author{
José Angelo Divino \\ Universidade Católica de Brasília \\ Renan Said Silva \\ Universidade Católica de Brasília
}

\section{Abstract}

This paper applies the Panzar-Rosse model to assess the level of competition in the Brazilian banking sector. The sample covers 62 banks in the period from July 1994 to February 2012. Special attention is paid to the presence of scale variables in the regression, the existence of seasonal components in the financial time series, and the normalization of the price of banking inputs. The inclusion of scale variables in the model and the presence of seasonality in the data tend to erroneously indicate a competitive market structure. Contrary to the literature, in the seasonally-adjusted model without scale variables, the $\mathrm{H}$-statistics indicates that banks in general and specific subgroups are non-competitive in the market. While large banks have high market power, public banks have intermediary market power, compatible with the various kinds of political interference in their management decisions.

\section{Keywords}

banking sector; market structure; H-statistics; panel data.

JEL Codes C33; G21; L11.

\section{Resumo}

Este artigo aplica o modelo Panzar-Rosse para avaliar o nivel de concorrência no setor bancário brasileiro. A amostra cobre 62 bancos no periodo de julho de 1994 a fevereiro de 2012. É dada especial atenção à presença de variáveis de escala na regressão, à existência de componentes sazonais nas séries temporais financeiras e à normalização do preço dos insumos bancários. A inclusão de variáveis de escala no modelo e a presença de sazonalidade nos dados tendem a indicar erroneamente uma estrutura de mercado competitiva. Contrariamente à literatura, no modelo ajustado sazonalmente sem variáveis de escala, a estatística H indica que os bancos em geral e subgrupos específicos não são competitivos no mercado. Enquanto os grandes bancos possuem alto poder de mercado, os bancos públicos têm poder de mercado intermediário, compativel com os vários tipos de interferência política em suas decisões de gestão.

\section{Palavras-chave}

setor bancário; estrutura de mercado; estatística

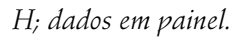

Códigos JEL C33; G21; L11. 


\section{Introduction}

Monetary authorities worldwide seek efficient ways to affect credit through monetary policy, but on many occasions, the transmission mechanisms might not be as effective as desired. One of the elements that might influence the transmission channels is the degree of concentration of the financial system. In many situations, it is convenient to assume that the financial market is perfectly competitive, implying that there are no distortions arising from that sector. However, this is a theoretical assumption hardly observed in practice.

In the financial system, banks have the basic function of intermediating transactions among savers and borrowers. The fulfillment of this task rests on profit maximization by the bank firm. Based on this principle, it is expected that private banks pursue this goal more vigorously than the public ones, which are subject to political interference in their management decisions. Thus, the degree of competition in the banking sector might also be affected by the participation of public banks in the financial sector.

A specific characteristic of the Brazilian financial system is the low degree of transmission of the monetary policy, which uses the basic interest rate to stabilize inflation. This implies that the basic interest rate has limited power to affect the economic activity through the credit channel. Considering that the organization of the financial system responds to particularities of the banking sector, we investigate elements of market power and concentration which are compatible with the idea of low competition in the Brazilian banking sector. Financial data from Central Bank of Brazil reveal that, in June 2012 and following periods, over $80 \%$ of the total deposits were distributed among only five financial institutions. Even though most of the deposits are concentrated in such a small number of banks, this does not necessarily mean that there is no competition in the financial market. To analyze bank competition in this environment, one should apply an unbiased method to investigate the banks' market structure and find out the degree of concentration within this market.

The objective of this paper is to apply the Panzar and Rosse (1987) model to assess the market structure of the Brazilian banking sector. Special attention is paid to the presence of scale variables in the regression, the existence of seasonal components in the financial series, and the normalization of the price of banking inputs. The sample covers 62 banks in 
the period from July 1994 to February 2012. Essentially, the Panzar-Rosse model identifies the market structure through the response of the total revenue to changes in the input prices. The model is theoretically well grounded, but its application requires special care, as pointed out by Bikker, Spierdijk and Shaffer (2012). The use of scale variables to control for size of the financial institutions, for instance, yields biased results. They showed that the revenue-elasticity with respect to the price of inputs is replaced by the price-elasticity of output with respect to the price of inputs when scale variables are added to the regression.

Another concern with the application of Panzar-Rosse is that the original model is timeless and designed for a single firm. In estimations, the H-statistics, which is an indicator of competition among banks, might not reveal the market structure of the banking sector, but rather provide an inaccurate value due to possible heterogeneity among banks. This heterogeneity arises because there are several institutions classified as banks, but with no guarantee that they target the same market or offer similar financial products.

When considering the temporal dimension, there are additional precautions to be taken, such as the presence of unit root and the existence of seasonal components in the series. There is also a discussion on the banking balance sheets, specifically on which type of revenue to evaluate, since revenues from different financial operations and services might have different relationships. The issue arises, for instance, because an institution might have market power in financial transactions but not in financial services, or vice versa.

The applied literature examining the Brazilian economy, with the exception of Tabak, Gomes, and Medeiros Jr. (2015), tends to conclude that the banking sector is competitive, despite the high concentration of deposits in a few financial institutions. Evidence of a competitive banking sector is provided by Lucinda (2010), Araújo, Jorge Neto, and Ponce (2006), Araújo and Jorge Neto (2007), and Nakane (2002). It is noteworthy that Lucinda (2010) applies the Panzar-Rosse model to panel data, while Tabak, Gomes, and Medeiros Jr. (2015) and Araujo and Jorge Neto (2007) perform the estimation for various cross sections. Nakane (2002) applies the model by Bresnahan (1982) and Lau (1982) to aggregate the time series of the Brazilian banking system. Belaisch (2003) also makes use of panel data and does not reject the hypothesis of competition in the Brazilian banking sector. At the aggregate state level, Sanches et al. (2009) estimate a dynamic 
panel and claim that the level of banking competition is high across the major Brazilian states.

Using non-structural estimation, most studies suggest the existence of competition in the Brazilian banking sector. ${ }^{1}$ This is the case when one considers estimations of the Panzar-Rosse model, whose results are biased towards a competitive market. Only Tabak, Gomes, and Medeiros Jr. (2015) found $\mathrm{H}$-statistics smaller than zero $(H<0)$ in 3 out of 21 estimates by cross section. The differences among the results are due to methodological aspects that need to be further developed by incorporating the Bikker, Spierdijk, and Shaffer (2012) criticism and dispensing appropriate treatments to the financial series involved in the estimation. Recently, Barbosa et al. (2015) also found evidence of a non-competitive market structure through the estimation of a negative adjusted $\mathrm{H}$-statistic. They extend the Panzar and Rosse's (1987) model to the case of a multi-product banking firm and argue that the market power of Brazilian banks is positively associated to the multi-product structure of banks.

This paper differs from other studies on the Brazilian banking sector because it applies the Panzar-Rosse model to a seasonally-adjusted database, considers the Bikker, Spierdijk and Shaffer (2012) criticism, and introduces an alternative way of computing relative prices of financial input by measuring administrative expense per unit of credit granted. Usually, total assets or total assets minus some ledger account, which might not change when the bank makes a credit operation, are used in the normalization. ${ }^{2}$ The estimated $\mathrm{H}$-statistics indicates a tendency of overestimating the degree of competition in the banking sector when using a database without seasonal adjustment or disregarding the Bikker, Spierdijk and Shaffer (2012) criticism in the estimation process. As consequence, our findings differ from previous studies that indicate some degree of competition in the Brazilian banking sector. Once the bias is corrected, we provide evidence that Brazilian banks do not operate in competitive markets. The big banks experience some degree of concentration and have market power significantly higher than that of the other financial institutions. Public banks have lower market power than banks in general, but they cannot be characterized as competitive.

1 By non-structural estimation, we mean that a theoretical model was not built and the parameters were not estimated for the resulting equilibrium equation.

2 Next section addresses this issue with more details. 
The paper is organized as follows. The second section presents the empirical model and discusses the estimation procedure. The third section describes the database. The fourth section displays and analyzes the results. Finally, the fifth section is dedicated to the concluding remarks.

\section{Empirical model}

The model developed by Panzar and Rosse (1987) applies comparative statics to the firm's problem in equilibrium. The major findings can be summarized into three results about the sum of the elasticities of total revenue with respect to prices of production inputs. The sum of these elasticities, also known as $\mathrm{H}$-statistics, serves as a measure of competition among firms in the market. According to Panzar and Rosse (1987), the main results are stated as follows ${ }^{3}$.

- Theorem 1: The sum of the elasticities of total revenue with respect to the price of production inputs in the reduced form revenue of a monopolist should not be positive $(H \leq 0)$.

- Proposition 1: In the Chamberlin symmetric equilibrium, the sum of the elasticities of total revenue with respect to the price of production inputs is less than or equal to $1(H \leq 1)$.

- Proposition 2: For firms observed in the long-run competitive equilibrium, the sum of the elasticities of total revenue with respect to the price of production inputs is $1(H=1)$.

It is worth mentioning that the $\mathrm{H}$-statistics for each firm $i$ is given by:

$$
H_{i}=\sum_{k=1}^{m} \frac{\partial R_{i}^{*}}{\partial w_{k i}} \frac{w_{k i}}{R_{i}^{*}}
$$

where $w_{k}$ is the price of the $k^{\text {th }}$ production input and $R^{*}$ is the revenue when the firm adopts the best production response.

The basic idea is that revenues of a monopolist or oligopolist negatively respond to increases in the price of any input. However, in the case of perfect competition, any rise in input prices is fully passed on to the price of the final product, leading to a proportional increase in revenue. In the intermediate

3 See Panzar and Rosse (1987) for a formal derivation of the firm's problem as well as for proofs of the results reproduced here. 
case of monopolistic competition, any increase in marginal cost will affect revenue as in the previous case, but with a less-than-proportional change.

The empirical implications of this model have been widely investigated in the literature. One of the most recognized applications is Bikker, Spierdijk and Shaffer (2012), who pointed out that the inclusion of scale variables in the empirical model biases the measure of concentration given by the H-statistics. Specifically, they argue that estimates for monopoly or oligopoly that control for the scale effect yield $H>0$. In addition, the inclusion of scale variables as independent variables results in $H>0$ for monopoly or oligopoly if the logarithm of total assets is included as a separate variable in the regression.

Bikker, Spierdijk, and Shaffer (2012) show that, after controlling for scale or adding a scale variable in the regression, the model is no longer estimated against the total revenue but instead against price. The simplest way to control for the scale effect is to use the logarithm of total revenue divided by total assets as dependent variable, which serves as a proxy for the logarithm of the price of output according to Bikker, Shaffer, and Spierdijk (2012). The inclusion of a scale variable in the equation usually consists of adding total assets as a regressor. When its estimated coefficient is statistically equal to one, the effect will be equivalent to using the logarithm of the price of output as dependent variable. In general, an increase in the price of inputs leads to a reduction in the revenue of the monopolist, but the price of the product will always be raised. Thus, in the regression against price, one has that $H>0$ even in a monopolistic market structure.

In Pazar and Rosse (1987) the results are obtained for a single firm in a timeless environment. Here, the model is adapted for a panel data environment. Thus, there is variability among individuals and over time, allowing for the estimation of average effects associated to these two dimensions.

The empirical model employs a control variable to represent the portfolio risk of each financial institution (CRD), which influences the supply and demand and helps to identify the model's parameters. Dummy variables $\left(D_{j}\right)$ are used to analyze the financial institutions by groups $(j=1, \ldots, J)$ and capture any heterogeneity in the parameters. The empirical model is described as:

$$
\begin{aligned}
& \ln \left(R T_{i t}\right)=\gamma_{0}+\beta_{1} \ln \left(w 1_{i t}\right)+\beta_{2} \ln \left(w 2_{i t}\right)+ \\
& +\sum_{j=1}^{J} D_{j}\left[\gamma_{0, j}+\beta_{1, j} \ln \left(w 1_{i t}\right)+\beta_{2, j} \ln \left(w 2_{i t}\right)\right]+\beta_{4} \ln \left(C R D_{i t}\right)+\stackrel{a}{i t}_{i t}
\end{aligned}
$$


where $i=1,2, \ldots, 62$ indexes the banks and $t=1994: 7,1994: 8, \ldots, 2012: 2$ represents the time period. The $\mathrm{H}$-statistics for banks in general, which does not belong to the control groups, is defined by $H=\beta_{1}+\beta_{2}$. For each subgroup, $j$, we have that $H_{j}=\beta_{1}+\beta_{2}+\beta_{1, j}+\beta_{2, j}$. In addition, RT is the total revenue from credit operations, $w 1$ is the administrative expense per unit of credit granted, and $w 2$ is the return on deposits. ${ }^{4}$

Differently from other studies, the input $w 1$ is measured as the administrative expense per unit of credit granted. Credit is the main product of a banking institution and solely responsible for revenues from credit operations. By considering credit as a product, $w 1$ is naturally the administrative cost per unit produced.

In other studies, administrative expenses are normalized by total assets or total assets minus some ledger account. They are described as the unit price of administrative expenses, but it is not clear to which unit of input it refers. Another criticism of using total assets to compute $w 1$ is that when the bank makes a credit operation it does not necessarily raise funds (increasing the asset), because it has the option of exchanging the level of highly liquid asset accounts for more credit operations (loan portfolio) which are also active accounts. Thus, the size of the loan portfolio might not be directly related to the size of the total assets.

In cases where administrative expenses and credit granted increase proportionally, there will be no change in administrative expenses per unit of credit given by (Adm. Exp./Credit), regardless of whether the bank conducts an active operation (rearranging its assets) or not. If the input is normalized by assets, (Adm. Exp./Assets), there will be an increase in this proxy, if the operation is active or partially active (where the increase of credit operations is enabled by fund raising). This way, the normalization by total assets might not correctly reveal the price of the input, especially in the case where only competition is being evaluated in the credit market.

Another key point is that the normalization by assets does not capture the increase in administrative productivity and economies of scale. For these effects to be captured, it is necessary that, to grant one unit of credit, another unit should be raised in the market. This rarely happens, given that it is well known that banks seek the maximum amount of deposits, regardless of whether they are able to lend or not such amounts. When 4 We also tried to control for other sources of time-dependent heterogeneity, but none of them were statistically significant in the estimations reported in sections 4.2 to 4.4 . 
normalized by credit granted, however, it is simple to capture the effect of productivity growth on costs, because the relationship itself already responds to increases in productivity and economies of scale. The relationship itself refers to the ratio between expenditure and product.

Following the criticism of Bikker, Shaffer and Spierdijk (2012), scale variables, such as fraction of market share, number of branches, and total assets, were not added to the empirical model since they might bias the results. According to Shaffer (1983), in the short run, the H-statistics should be evaluated with a one-tailed test, in which case a value smaller than zero rejects any form of imperfect competition while positive values are coherent with various structures of competition. For intermediate values, two null hypotheses are tested:

The null hypotheses of monopoly/oligopoly: $H \leq 0$

The null hypotheses of perfect competition: $H=1$

From these, it is possible to make inferences about the market structure. If both hypotheses are rejected, one might infer that the market structure is compatible with monopolistic competition. Shaffer $(1982,1983)$ and Vesala (1995) extended the Panzar-Rosse model and showed that, under certain conditions, the $\mathrm{H}$-statistics increases with the degree of competition. In particular, Vesala (1995) shows the existence of a negative relationship between the $\mathrm{H}$-statistics and market power in the case of monopolistic competition with free entry. Thus, it is possible to make an association between the $\mathrm{H}$-statistics and the degree of competition.

The panel data estimation should account for the presence of either fixed effects or random effects in the composite error of the regression, which is defined as $\varepsilon_{i t}=\delta_{i}+u_{i t}$, where $\delta_{i}$ is the individual heterogeneity and $u_{i t}$ is the idiosyncratic error term. Basically, the fixed effects are associated with individual heterogeneity and might bias the estimates if the latter is correlated with the regressors. The random effects are not correlated with the regressors and do not bias the estimates but compromise the model's efficiency. The variance of the composite error depends on the variance of the idiosyncratic error term and the individual effect, $\delta_{i}$, which is the source of the random effects.

Following the classical approach, the treatment of these effects requires application of appropriate fixed effects or random effects estimator. The 
first is obtained by subtracting the within-groups average from the variables, which allows eliminating the individual heterogeneity. The random effects estimator is computed by GLS, correcting the variance-covariance matrix for the effects of the individual heterogeneity. The Hausman test is applied to determine which estimator, random or fixed effects, is best suited to the database.

\section{Data}

The database was obtained from Central Bank of Brazil and refers to balance sheets of several financial institutions. The frequency is monthly, covering the period from July 1994 to February 2012 for 62 banks. The data available from Central Bank of Brazil had an irregular shape and was organized into a balanced panel. ${ }^{5}$ The variables and respective account numbers in the balance sheets are reported in Table 1.

The variables used in the empirical model were constructed from the balance sheets of the banks, as described in Table 2. These variables were not deflated whenever expressed as accounting ratios. Only income from lending operations was deflated by the wide consumer price index (IPCA).

Table 1 Account codes

\begin{tabular}{lr}
\hline 71100001 & Income from lending operations \\
\hline 16000001 & Lending operations \\
\hline 46000002 & Borrowing and lending operations \\
\hline 81100008 & Borrowing expenses \\
\hline 81200001 & Expenses for borrowing and transfers \\
\hline 41000007 & Deposits \\
\hline 81700006 & Administrative expenses \\
\hline 40000008 & Current and long term liabilities \\
\hline
\end{tabular}

5 The procedure stacked monthly files for each financial institution and handled more than 4.5 million lines of information. Visualization, manipulation, and organization of the observations were performed in the software SAS. We developed a specific code to organize the stacked data in the format of a balanced panel data. The computer code consisted of separating the accounts of interest and merging data in multiple columns, with one column for each account information, and lines, used to identify the bank and date of the observation, in the format of a balanced panel. 
A simple graphical inspection of the series revealed that seasonality was a striking feature of some variables. This is illustrated in Figure 1 for a representative bank, whose identity is not revealed for confidentiality reasons. The seasonal component was removed through the application of the filter CENSUS X12, provided by the United States Census Bureau, which is widely used in the treatment of seasonality in time series. The only variable that showed no seasonal movements, and consequently was not filtered, was the (log of) risk of the portfolio [called $\ln (C R D)$ ], which was included as a control variable in the estimated models.

Table 2 Definition of the variables

\begin{tabular}{cr}
\hline$W 1=\frac{\text { Administrative expenses }}{\text { Lending operations }}$ & $\begin{array}{r}\text { Administrative remuneration } \\
\text { per unit of credit granted }\end{array}$ \\
\hline$W 2=\frac{\text { Borrowing expenses }}{(\text { Deposits }+ \text { Current and long term liabilities })}$ & $\begin{array}{r}\text { Remuneration } \\
\text { for deposits }\end{array}$ \\
\hline$C R D=\frac{\text { Lending operations }}{(\text { Deposits }+ \text { Borrowing and lending operations) }}$ & $\begin{array}{r}\text { Risk from financial } \\
\text { intermediation exposure }\end{array}$ \\
\hline$R T_{O C}=$ Income from lending operations & $\begin{array}{r}\text { Total revenue from } \\
\text { credit operations }\end{array}$ \\
\hline
\end{tabular}

The seasonal movements are due to the occurrence of specific events in some periods of the year such as the payment of the $13^{\text {th }}$ salary in December and other synchronized procedures in the release of accounting information. Banks have to follow accounting rules and handling accounting information might depend on the managers' intentions, profit distribution policies, disclosure of financial results, capital structure of the institution, if it is public or privately owned, and other elements. Taken together, all previous elements contribute to introduce a typical oscillatory movement in the time series, which characterizes the seasonal component.

As illustrated in Figure 1, there is a significant difference between the seasonally-adjusted series and the unadjusted ones for a representative bank. ${ }^{6}$ In all previous studies, there was no reference to the seasonal component of the balance sheet series. The lack of treatment for the seasonality might affect the empirical results concerning the degree of competition

6 Figure 1 displays only a representative bank because of the difficulty to plot and jointly format the series of all 62 banks. However, the series for all remaining banks showed similar patterns. 
in the Brazilian banking sector, as it will be shown in the next section. ${ }^{7}$

Our interest is to evaluate the effects of cycle and trend components on banking concentration in Brazil. The seasonal component shall be eliminated from the time series because it represents a simple regular oscillation that occurs in specific periods of the year and that is not related to those components. It does not matter whether this seasonal component will under or overestimate bank competition. It only matters that the estimator is affected and, therefore, seasonality must be adequately treated. For comparison purposes, we report estimations for time series with and without seasonal adjustment.

The Census X12 filter was applied to each time series individually in order to adjust for seasonality. The model was then estimated using the seasonally-adjusted series. In the presence of seasonality, the estimated coefficients might be biased and the explanatory power of the model might be artificially inflated. The preliminary adjustment prevents seasonal movements from hindering the identification of the relationship between the variables.

The classification by Central Bank of Brazil available in the balance sheets was used to classify each bank in the sample as public (PUB), development (DES), investment (INV), foreign (EXT), and large (GRD), not necessarily mutually exclusive. The group of large institutions (GRD) was rated as the top five institutions according to the highest values of total assets in the balance sheets of February, 2012. Comparing the total assets of these five major banks, the smallest of them accounted for $43 \%$ of the total assets of the largest one. In addition, the sixth bank in the general classification had only $14 \%$ of the total assets of the largest bank. This means that the fifth largest bank is more than three times larger than the sixth one. Because of this disparity, they are commonly called the top five Brazilian banks.

The identification of each institution was possible through its unique CNPJ (Corporate Taxpayer Registry) number, which facilitates the organization and manipulation of the banks. Thus, changes in names or classifications of banks during the period did not generate any difficulty for the

7 It is worth mentioning that the effects of seasonality might be smaller in lower frequency data (semi-annual, for instance). Thus, the potential problems for the estimates might be smaller in Belaisch (2003) and Araújo and Jorge Neto (2007), who used semi-annual data, and Lucinda (2010), who used quarterly data, when compared to our estimates, which are based on monthly data. 
organization of information. The utilization of CNPJ also allows keeping in the data set those institutions which have acquired or incorporated other ones and exclude those which have been extinguished or incorporated when building a balanced panel data. It is also necessary to point out that many institutions have changed their classification in the period and the correspondent qualitative variables followed those changes.

\section{Figure 1 Balance sheet series of a representative bank}
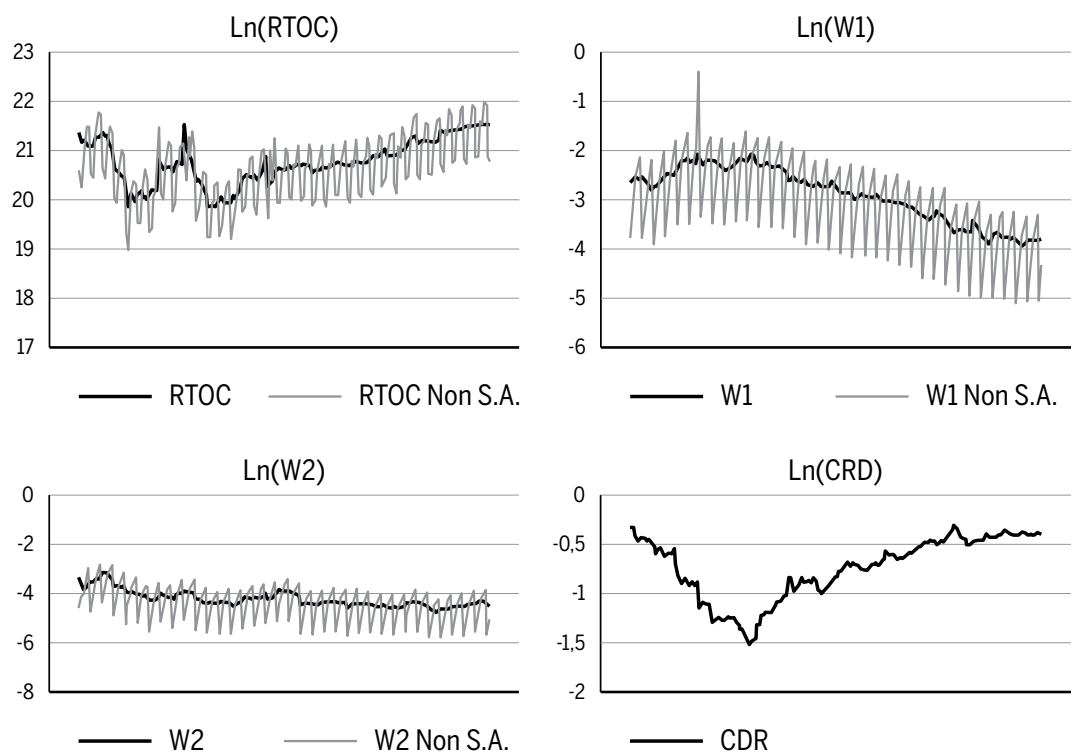

\section{Results}

\subsection{Unit root tests}

In a panel data, as in the time-series environment, there is a concern about stationarity of the variables because the presence of a unit root might lead to the estimation of a spurious regression when the residuals are not stationary. To test for the presence of unit root in the balanced panel, we applied the tests proposed by Levin-Lin-Chu (2002), called LLC, Im, Pesaran and Shin (2003), known as IPS, Fisher and Choi (2001), and Harris and Tzvalis (1999), or HT for short. We apply all these different tests in order to get some complementarity in the results. For instance, LLC and HT tests are for common unit root, 
while IPS and Fisher tests deal with individual unit root; LLC and HT can be applied only for strongly balanced panel; and IPS accepts unbalanced panel but with no gaps in each individual series. The results are reported in Table 3. The variables $\ln \left(R T_{O C}\right), \ln (w 1)$, and $\ln (w 2)$ were seasonally-adjusted.

Table 3 Unit root tests

\begin{tabular}{|c|c|c|c|c|}
\hline & \multicolumn{2}{|r|}{ LLC } & \multicolumn{2}{|c|}{ HT } \\
\hline & $\{1\}$ & $\{1, \mathrm{t}\}$ & $\{\mathbf{1}\}$ & $\{1, t\}$ \\
\hline $\operatorname{Ln}\left(R T_{o c}\right)$ & 0.0514 & $* * *-6.7960$ & $* * *-4.60 \mathrm{E}+02$ & $* * *-3.20 \mathrm{E}+02$ \\
\hline $\operatorname{Ln}(w 1)$ & -0.8017 & *-1.4964 & $* * *-14.0881$ & ***-11.2737 \\
\hline $\operatorname{Ln}(w 2)$ & ***-13.0817 & $* * *-13.2441$ & $* * *-25.2484$ & ***-19.1862 \\
\hline \multirow[t]{3}{*}{$\operatorname{Ln}(C R D)$} & $* * *-4.2043$ & $* * *-5.3414$ & $* * *-23.7743$ & $* * *-13.2879$ \\
\hline & & IPS & & FISHER \\
\hline & $\{1\}$ & $\{1, \mathrm{t}\}$ & $\{1\}$ & $\{1, t\}$ \\
\hline $\operatorname{Ln}\left(R T_{o c}\right)$ & $* * *-14.8313$ & $* * *-19.9212$ & $* * *-13.8251$ & ***-15.9707 \\
\hline $\operatorname{Ln}(w 1)$ & -0.8433 & $* * *-2.5674$ & -0.4649 & $* *-1.8373$ \\
\hline $\operatorname{Ln}(w 2)$ & $* * *-16.2008$ & $* * *-18.4215$ & $* * *-15.6576$ & ***-16.8314 \\
\hline $\operatorname{Ln}(C R D)$ & $* * *-8.5669$ & $* * *-8.0630$ & $* * *-8.1736$ & $* * *-7.2236$ \\
\hline
\end{tabular}

Notes: Lags selected by the Akaike information criteria. * Reject the null at 10\% of significance;

** Reject the null at $5 \%$ of significance; *** Reject the null at $1 \%$ of significance.

The LLC test shows different results depending on the model's specifications. In the equation without trend, the null of unit root was not rejected for $\ln (w 1)$ and $\ln \left(R T_{O C}\right)$. By adding the trend, however, the unit root hypothesis was rejected at the $10 \%$ significance level for $\ln (w 1)$ and at $1 \%$ for all other variables.

The IPS test indicated that, except for $\ln (w 1)$, all variables are stationary at the $1 \%$ significance level with the inclusion of a constant. Adding a constant and a trend, all variables are stationary at the $1 \%$ significance level. Similarly to LLC test, $\ln (w 1)$ is stationary only in the equation that includes trend as a deterministic term.

The FISHER test practically reproduced IPS results. The only difference was that in the specification with constant and trend, $\ln (w 1)$ rejected $H_{0}$ with $5 \%$ of significance rather than $1 \%$ as in the IPS test. This similarity demonstrates convergence among results of the two tests, especially with the inclusion of trend to evaluate $\ln (w 1)$. Only in the HT test, did all panels reject the null of unit root at the $1 \%$ significance level for both specifica- 
tions. The LLC test, despite having the same null hypothesis as the HT, required the inclusion of a linear trend to reject unit root for all variables.

The results from these four tests led to the conclusion that the panel is stationary. In general, it is sufficient to include a constant as a deterministic term in the test equations to render stationarity for all variables. These findings validate the estimation of equation (1) in log-level without incurring any spurious regression.

Given the stationarity of all variables, Table 4 reports the estimates for the basic model under the assumptions of fixed effects (FE) and random effects (RE) in order to apply the Hausman test. The difference between the two estimates is very small when comparing the sum of the squared error. The Hausman test for the difference between the coefficients did not reject the hypothesis of identical estimates. This result indicates that the specific individual heterogeneity is not correlated with the regressors. Thus, the Hausman test recommends the estimation of the random effects model. As previously stated, the RE model shall be estimated by GLS to correct the variance-covariance matrix for the presence of unknown heteroskedasticity. ${ }^{8}$

\section{Table 4 Hausman test}

\begin{tabular}{l|rrrr}
\hline & FE & RE & S.E. \\
\hline $\operatorname{Ln}(w 1)$ & -0.3637 & -0.3659 & $(0.0024)$ \\
\hline $\operatorname{Ln}(w 2)$ & -0.0790 & -0.0773 & $(0.0013)$ \\
\hline $\operatorname{Ln}(C R D)$ & 0.3626 & 0.3601 & $(0.0024)$ \\
\hline$\chi^{2}(3)=2.51$ & & & P-value $=0.4739$ \\
\hline
\end{tabular}

\subsection{Seasonal adjustment}

The results obtained from the seasonally-adjusted data indicated that the Brazilian banking sector is less competitive than what is usually found in other studies that do not perform this adjustment before estimation. ${ }^{9}$ Us-

8 The results for the basic model estimated under FE and RE reported in Table 4 indicates that there is no significant difference between the coefficients estimated from these two alternative specifications. Thus, there is also no significant difference in the $\mathrm{H}$-statistics estimated from each one of those models. Specifically, the H-statistics were -0.4427 and -0.4432 for the FE and RE models, respectively.

9 According to the Frisch-Waugh-Lovell theorem, it is irrelevant whether one uses seasonal 
ing non-seasonally-adjusted data, all estimates of the $\mathrm{H}$-statistics were significantly larger and always positive $(H>0)$, according to other studies on the Brazilian economy. This finding suggests that a preliminary treatment of the banking time series is crucial for the assessment of the level of competition in the sector. If seasonality is not removed from the database, all bank profiles would be erroneously classified as operating in monopolistic competition. This result is in accordance with Belaisch (2003), Lucinda (2010) and Araujo and Jorge Neto (2007), who do not mention any treatment for seasonal effects in their database.

Table 5 presents, side by side, the estimates from the seasonally-adjusted and non-seasonally-adjusted series. Comparing the results, several coefficients show significant changes between the two models. In addition, the explanatory power of the regression is higher in the seasonallyadjusted model, as illustrated by the $\mathrm{R}^{2}$ of 0.3043 against 0.2563 in the non-seasonally-adjusted model.

Table 5 Effects of seasonality in the estimated models

\begin{tabular}{|c|c|c|}
\hline Variable & Seasonally-adjusted & Non-seasonally-adjusted \\
\hline $\operatorname{Ln}(w 1)$ & $\begin{array}{r}* * *-0.4070 \\
(0.0316)\end{array}$ & $\begin{array}{l}-0.0006 \\
(0.0282)\end{array}$ \\
\hline $\operatorname{Ln}(w 2)$ & $\begin{array}{r}* * *-0.1025 \\
(0.0264)\end{array}$ & $\begin{array}{r}{ }^{* * *} 0.1061 \\
(0.0260)\end{array}$ \\
\hline$g w 1_{m}$ & $\begin{array}{r}* * *-0.6115 \\
(0.1046)\end{array}$ & $\begin{array}{r}* * *-0.6156 \\
(0.1005)\end{array}$ \\
\hline$g w 2_{m}$ & $\begin{array}{r}* * * 0.3143 \\
(0.1576)\end{array}$ & $\begin{array}{r}{ }^{* * *} 0.7892 \\
(0.1211)\end{array}$ \\
\hline$p w 1_{m}$ & $\begin{array}{r}0.0606 \\
(0.0999)\end{array}$ & $\begin{array}{r}0.0958 \\
(0.0908)\end{array}$ \\
\hline$p w 2_{m}$ & $\begin{array}{r}{ }^{* *} 0.2187 \\
(0.1127)\end{array}$ & $\begin{array}{r}{ }^{* *} 0.2204 \\
(0.0975)\end{array}$ \\
\hline$e w 1_{m}$ & $\begin{array}{r}* *-0.1247 \\
(0.0709)\end{array}$ & $\begin{array}{r}-0.0894 \\
(0.0647)\end{array}$ \\
\hline
\end{tabular}

(continues on next page)

dummies in the regression or if the variable is first seasonally adjusted (by the same dummy variable method), and then the regression is estimated. As the estimation of a regression with seasonal dummies is part of the procedure applied by the Census X12, the results obtained with the inclusion of dummies variables in a regression with unadjusted time series are very similar to the ones reported in Table 5. 
Table 5 (continued)

\begin{tabular}{|c|c|c|}
\hline Variable & Seasonally-adjusted & Non-seasonally-adjusted \\
\hline \multirow[t]{2}{*}{$e w 2_{m}$} & $* * * 0.2310$ & $* * * 0.1664$ \\
\hline & $(0.0618)$ & $(0.0597)$ \\
\hline \multirow[t]{2}{*}{$i w 1_{\mathrm{m}}$} & $* * * 0.7570$ & $* * * 0.5495$ \\
\hline & $(0.0869)$ & $(0.0881)$ \\
\hline \multirow[t]{2}{*}{$i w 2_{m}$} & 0.2505 & -0.1397 \\
\hline & $(0.1595)$ & $(0.1264)$ \\
\hline \multirow[t]{2}{*}{$d w 1_{\mathrm{m}}$} & 0.2223 & $* * * 0.3695$ \\
\hline & $(0.1895)$ & $(0.1164)$ \\
\hline \multirow[t]{2}{*}{$d w 2_{\mathrm{m}}$} & -0.0393 & $* * *-0.2420$ \\
\hline & $(0.0470)$ & $(0.0475)$ \\
\hline \multirow[t]{2}{*}{$\operatorname{Ln}(C R D)$} & $* * * 0.3571$ & $* * * 0.6229$ \\
\hline & $(0.0341)$ & $(0.0343)$ \\
\hline \multirow{2}{*}{$\operatorname{grd}_{n}$} & $* * * 3.7208$ & $* * * 5.7003$ \\
\hline & $(0.9158)$ & $(0.7469)$ \\
\hline \multirow[t]{2}{*}{ pub $_{n}$} & $* * * 2.6819$ & $* * * 2.7597$ \\
\hline & $(0.7127)$ & $(0.6048)$ \\
\hline \multirow{2}{*}{ ext $_{n}$} & $* * * 0.8616$ & $* * * 0.8025$ \\
\hline & $(0.2868)$ & $(0.2403)$ \\
\hline \multirow[t]{2}{*}{$\operatorname{inv}_{n}$} & $* * * 2.9394$ & ${ }^{*} 0.7668$ \\
\hline & $(0.5761)$ & $(0.4054)$ \\
\hline \multirow[t]{2}{*}{$\operatorname{des}_{n}$} & 1.0808 & 1.4851 \\
\hline & $(1.3298)$ & (1.1219) \\
\hline \multirow[t]{2}{*}{ _cons } & $* * * 13.8941$ & $* * * 16.0372$ \\
\hline & $(0.2264)$ & $(0.2116)$ \\
\hline $\mathrm{R}^{2}$ & 0.3049 & 0.2544 \\
\hline $\mathrm{N}$ & 13144 & 13144 \\
\hline
\end{tabular}

Notes: subscript $m$ represents the multiplicative dummy for the group of banks: large ( $g)$, public (p), foreign (e), investment (i), and development (d). Subscript $n$ stands for level dummies for large banks (grd), public banks (pub), foreign banks (ext), investment banks (inv), and development banks (des). $*^{* *},{ }^{* *}$, and ${ }^{*}$ - statistically significant at the 1,5 and $10 \%$ significance levels, respectively. $N$ is the number of observations. Robust standard errors are in parenthesis.

The coefficients that form the $\mathrm{H}$-statistics are also affected by the seasonality in the data. The values of $\ln (w 1)$ and $\ln (w 2)$ in the seasonally-adjusted model are significantly lower than those computed in the non-seasonallyadjusted model. There are significant changes in $g w 2, i w 1, i w 2$, and $d w 2$ 
among the control groups, with some increasing and others decreasing the estimated coefficients. As the computation of the $\mathrm{H}$-statistics requires a joint analysis of these coefficients, we have to observe the changes in the $\mathrm{H}$-statistics in order to identify the effects of the seasonal adjustment for the market structure for the Brazilian banking sector.

The behavior of the H-statistics in the non-seasonally-adjusted data is quite different from the seasonally-adjusted one, as reported in Table 6. In the first case, all control groups showed positive $\mathrm{H}$-statistics $(H>0)$, resulting in market structures of imperfect or monopolistic competition. Only for the development banks, did the test not reject the non-competitive hypothesis $(H \leq 0)$. For the seasonally-adjusted data, however, the result is the opposite. The group of investment banks presented positive H-statistics, which is consistent with imperfect competition. All other groups displayed negative $\mathrm{H}$-statistics, which are not compatible with competitive market structures. These results reveal a tendency to overestimate the $\mathrm{H}$-statistics when there is seasonality in the data which is not treated prior to the estimation.

Table 6 Seasonal adjustment and $\mathrm{H}$-statistics

\begin{tabular}{lrr}
\hline Banks & Seasonally-adjusted & Non-seasonally-adjusted \\
\hline H_grd & $-0.8066^{* * *}$ & $0.2791^{* * *}$ \\
& $(0.1696)$ & $(0.0870)$ \\
\hline H_pub & $-0.2302^{*}$ & $0.4218^{* * *}$ \\
& $(0.1293)$ & $(0.0669)$ \\
\hline H_ext & $-0.4033^{* * *}$ & $0.1826^{* * *}$ \\
& $(0.0793)$ & $(0.0592)$ \\
\hline H_inv & $0.4979^{* * *}$ & $0.5153^{* * *}$ \\
& $(0.1386)$ & $(0.0889)$ \\
\hline H_des & $-0.3265^{*}$ & $0.2330^{* *}$ \\
& $(0.1942)$ & $(0.1131)$ \\
\hline H_geral & $-0.5095^{* * *}$ & $0.1055^{* * *}$ \\
& $(0.0337)$ & $(0.0235)$ \\
\hline
\end{tabular}

Notes: ${ }^{* * *}$ - $P$-value $<0.01 ;{ }^{* *}$ - $P$-value $<0.05 ;{ }^{*}-P$-value $<0.10$ for the Wald test.

The results for the non-seasonally-adjusted model are close to those of Tabak, Gomes, and Medeiros Júnior (2015), who used a similar database. Lucinda (2010) attempted to estimate a model without including scale 
variables (not reported in his paper), but argued that the estimates of the $\mathrm{H}$-statistics were even greater than when scale variables were included. Finally, it is noteworthy that the similarity of the non-seasonally-adjusted results from Table 5 with those of Tabak, Gomes, and Medeiros Junior (2015) reinforces the fact that omitting such treatment might bias the assessment of the correct market structure for the Brazilian banking sector.

\subsection{Scale variables}

The inclusion of scale variables in the estimation of banking competition is a recurring theme in the literature. Their effects in a seasonally-adjusted environment, however, are not yet well explored. The log of total deposits ${ }^{10}$ was added as an explanatory variable in the models presented in Table 5 and the new results are reported in Table 7 . This represents a scale variable also used in other studies as control for the size of banks. ${ }^{11}$ The effects appear in the different values of the estimated coefficients by the adjusted and unadjusted models for seasonality.

Comparing the results from Tables 7 and 5 , one can see that most coefficients, for both models, suffered changes, which reflects a relationship between price of inputs and revenue. According to Bikker, Shaffer and Spierdijk (2012), the estimated regression would no longer represent the reduced-form revenue but, instead, the effect of the price of the good as the coefficient of the scale variable approaches the unit. In Table 7, this coefficient is between 0.43 and 0.51 , indicating an intermediate case. The explanatory power of the models, with $R^{2}$ coefficients near $50 \%$, is relatively high. Considering the basic model, without dummy variables, the value of $R^{2}$ was almost the same, suggesting that the inclusion of Total Deposits as an explanatory variable might reduce the ability of the dummies to add information to the estimated model.

The effects of including scale variables might be observed by calculating the $\mathrm{H}$-statistics, as reported in Table 8, which also replicates the values from Table 6. Comparing the $\mathrm{H}$-statistics with and without scale variable, the estimated coefficients are quite different. The $\mathrm{H}$-statistics

10 In the seasonally adjusted model, the variable total deposits was filtered to remove the seasonal component and deflated by IPCA. The unit root tests indicated that it is stationary. 11 Total assets is another commonly used scale variable in the literature. 
for both models, with and without seasonal adjustment, are smaller in absolute value. Only development banks showed an $\mathrm{H}$-statistics slightly larger in absolute value. In general, the increase is greater for the seasonally-adjusted model.

The scale variable might bias the estimates and affect the analysis of competition for public banks, which display an H-statistics compatible with competitive markets. Investment banks do not reject the hypothesis of perfect competition. The changes in the $\mathrm{H}$-statistics also affect the ranking of market power for each group of institutions.

Table 7 Estimations with a scale variable

\begin{tabular}{|c|c|c|}
\hline Variable & Seasonally-adjusted & Non-seasonally-adjusted \\
\hline $\operatorname{Ln}(w 1)$ & $\begin{array}{r}* * * 0.1335 \\
(0.0321)\end{array}$ & $\begin{array}{r}*{ }^{* *} 0.2141 \\
(0.0282)\end{array}$ \\
\hline $\operatorname{Ln}(w 2)$ & $\begin{array}{r}* * * 0.1788 \\
(0.0258)\end{array}$ & $\begin{array}{r}-0.0400 \\
(0.0255)\end{array}$ \\
\hline$g w 1_{m}$ & $\begin{array}{r}* * * 0.2817 \\
(0.1046)\end{array}$ & $\begin{array}{r}* * * 0.2861 \\
(0.0996)\end{array}$ \\
\hline$g w 2_{m}$ & $\begin{array}{r}{ }^{* *} 0.3994 \\
(0.1571)\end{array}$ & $\begin{array}{r}* * * 0.5354 \\
(0.1200)\end{array}$ \\
\hline$p w 1_{m}$ & $\begin{array}{r}-0.0014 \\
(0.0977)\end{array}$ & $\begin{array}{r}-0.0617 \\
(0.0888)\end{array}$ \\
\hline$p w 2_{m}$ & $\begin{array}{r}* * * 0.4496 \\
(0.1123)\end{array}$ & $\begin{array}{r}* *{ }^{* *} 0.4185 \\
(0.0958)\end{array}$ \\
\hline$e w 1_{m}$ & $\begin{array}{r}-0.0750 \\
(0.0691)\end{array}$ & $\begin{array}{r}-0.0679 \\
(0.0624)\end{array}$ \\
\hline$e w 2_{m}$ & $\begin{array}{r}* * 0.2652 \\
(0.0600)\end{array}$ & $\begin{array}{r}* * 0.2169 \\
(0.0574)\end{array}$ \\
\hline$i w 1_{m}$ & $\begin{array}{r}* * 0.5401 \\
(0.0827)\end{array}$ & $\begin{array}{r}* * 0.3683 \\
(0.0834)\end{array}$ \\
\hline$i w 2_{m}$ & $\begin{array}{r}* * * 0.4690 \\
(0.1575)\end{array}$ & $\begin{array}{r}0.0400 \\
(0.1229)\end{array}$ \\
\hline$d w 1_{\mathrm{m}}$ & $\begin{array}{l}-0.0368 \\
(0.1469)\end{array}$ & $\begin{array}{r}* * 0.2085 \\
(0.1046)\end{array}$ \\
\hline$d w 2_{\mathrm{m}}$ & $\begin{array}{r}* *-0.1490 \\
(0.0463)\end{array}$ & $\begin{array}{r}* * *-0.3042 \\
(0.0465)\end{array}$ \\
\hline
\end{tabular}

(continues on next page) 
Table 7 (continued)

\begin{tabular}{lrrr}
\hline Variable & Seasonally-adjusted & Non-seasonally-adjusted \\
\hline $\operatorname{Ln}(C R D)$ & $* * * 0.6596$ & $* * * 0.9054$ \\
& $(0.0351)$ & $(0.0344)$ \\
\hline grd $_{\mathrm{n}}$ & $* * * 3.0874$ & $* * * 3.3105$ \\
& $(0.6786)$ & $(0.4293)$ \\
\hline pub $_{\mathrm{n}}$ & $* * * 2.6729$ & $* * * 2.2203$ \\
& $(0.5041)$ & $(0.3384)$ \\
\hline ext $_{\mathrm{n}}$ & $* * 0.7059$ & $* * 0.5489$ \\
& $(0.2835)$ & $(0.2360)$ \\
\hline inv $_{\mathrm{n}}$ & $* * * 3.4081$ & $* * * 1.3014$ \\
& $(0.5606)$ & $(0.3924)$ \\
\hline des $_{\mathrm{n}}$ & -1.0710 & -0.2705 \\
& $(0.7768)$ & $(0.5977)$ \\
\hline Deps & $* * * 0.4300$ & $* * * 0.5122$ \\
& $(0.0168)$ & $(0.0167)$ \\
\hline cons & $* * * 8.6607$ & $* * * 9.2109$ \\
\hline $\mathrm{R}$ & $(0.2459)$ & $(0.2469)$ \\
\hline $\mathrm{N}$ & 0.521 & 0.4984 \\
\hline
\end{tabular}

Notes: subscript $m$ represents the multiplicative dummy for the group of banks: large ( $g$ ), public (p), foreign (e), investment (i), and development (d). Subscript $n$ stands for level dummies for large banks (grd), public banks (pub), foreign banks (ext), investment banks (inv), and development banks (des). ${ }^{* * *},{ }^{* *}$, and ${ }^{*}$ - statistically significant at the 1,5 and $10 \%$ significance levels, respectively. $N$ is the number of observations. Robust standard errors are in parenthesis.

Banks in general, in the seasonally unadjusted model of Table 8 with scale variable, have a lower $\mathrm{H}$-statistics than that obtained by Belaisch (2003), Araújo and Jorge Neto (2007) and Lucinda (2010), but higher than Tabak, Gomes, and Medeiros Junior (2015). For the control groups, the model without seasonal adjustment and with scale variables presented $0<H<1$. This result indicates the existence of monopolistic competition in the banking sector, as do most of the empirical works in the literature for the Brazilian economy.

One can also observe that the inclusion of scale variable in the estimated regressions overestimates the $\mathrm{H}$-statistics for both commercial and investment banks. However, it underestimates the H-statistics for development banks, regardless of the seasonal adjustment of the data. 
Table 8 Estimated values for the $\mathrm{H}$-statistics

\begin{tabular}{l|rr|r|r}
\hline Bank type & \multicolumn{2}{|c|}{ With scale variable } & \multicolumn{2}{r}{ Without scale variable } \\
\cline { 2 - 5 } & $\begin{array}{r}\text { Seasonally- } \\
\text {-adjusted }\end{array}$ & $\begin{array}{r}\text { Non-seasonally- } \\
\text {-adjusted }\end{array}$ & $\begin{array}{r}\text { Seasonally- } \\
\text {-adjusted }\end{array}$ & $\begin{array}{r}\text { Non-seasonally- } \\
\text {-adjusted }\end{array}$ \\
\hline H_grd & -0.1945 & $* * * 0.4235$ & $* * *-0.8066$ & $* * * 0.2791$ \\
& $(0.1702)$ & $(0.0862)$ & $(0.1696)$ & $(0.0870)$ \\
\hline H_pub & 0.1359 & $* * * 0.5309$ & $*{ }^{*}-0.2302$ & $* * * 0.4218$ \\
& $(0.1282)$ & $(0.0663)$ & $(0.1293)$ & $(0.0669)$ \\
\hline H_ext & -0.1220 & $* * * 0.3232$ & $* * *-0.4033$ & $* * * 0.1826$ \\
& $(0.0793)$ & $(0.0586)$ & $(0.0793)$ & $(0.0592)$ \\
\hline H_inv & $* * * 0.6969$ & $* * * 0.5825$ & $* * * 0.4979$ & $* * * 0.5153$ \\
& $(0.1368)$ & $(0.0877)$ & $(0.1386)$ & $(0.0889)$ \\
\hline H_des & $* * *-0.4981$ & 0.0784 & $* 0.3265$ & $* * 0.2330$ \\
& $(0.1507)$ & $(0.1019)$ & $(0.1942)$ & $(0.1131)$ \\
\hline H_geral & $* * *-0.3123$ & $* * * 0.1741$ & $* * *-0.5095$ & $* * * 0.1055$ \\
& $(0.0328)$ & $(0.0230)$ & $(0.0337)$ & $(0.0235)$ \\
\hline
\end{tabular}

Notes: ${ }^{* *}$ - $P$-value $<0.01$; ${ }^{*}$ - $P$-value $<0.05 ;{ }^{*}-P$-value $<0.10$ for the Wald test.

In addition to the seasonal adjustment and inclusion of a scale variable in the regressions, it is necessary to emphasize the change in computation of the administrative remuneration per unit of credit ( $w 1)$. In general, this variable is separated into average earnings of the workforce and unit price of other costs, such as physical capital, administrative expenses or nonoperating expenses. Here, this variable is defined in terms of units of its output, which is credit granted and not total assets. With $w 1$ expressed per unit of credit granted and separating the panel on sequential cross sections, the result $H<0$ was maintained in all scenarios: seasonally-adjusted, nonseasonally-adjusted, with or without scaling variables.

\subsection{Market structure of the banking sector}

The effects of including dummy variables in the regressions to control for group-specific heterogeneity are reported in Table 9. The group-specific coefficients indicate that big banks, public banks, and development banks suffered modifications in relation to the complete model. However, this change was not sufficient to affect their classification according to the 
$\mathrm{H}$-statistics. This happens because these three groups are not mutually exclusive, having banks that enter in more than one classification. The complete regression shall be used in the analysis because it controls for the profile of each kind of institution.

Table 9 Estimations for the complete model and specific groups

\begin{tabular}{|c|c|c|c|c|c|c|c|}
\hline & Complete & Big & Public & Foreign & $\begin{array}{r}\text { Invest- } \\
\text { ment }\end{array}$ & $\begin{array}{r}\text { Develop- } \\
\text { ment }\end{array}$ & Basic \\
\hline $\operatorname{Ln}(w 1)$ & $\begin{array}{r}* * *-0.4070 \\
(0.0316)\end{array}$ & $\begin{array}{r}* * *-0.3313 \\
(0.0287)\end{array}$ & $\begin{array}{r}* * *-0.3581 \\
(0.0288)\end{array}$ & $\begin{array}{r}* * *-0.3511 \\
(0.0292)\end{array}$ & $\begin{array}{r}* * * 0.4342 \\
(0.0285)\end{array}$ & $\begin{array}{r}* * *-0.3788 \\
(0.0287)\end{array}$ & $\begin{array}{r}* * * 0.3659 \\
(0.0282)\end{array}$ \\
\hline $\operatorname{Ln}(w 2)$ & $\begin{array}{r}* * *-1025 \\
(0.0264)\end{array}$ & $\begin{array}{r}* * * 0.0868 \\
(0.0200)\end{array}$ & $\begin{array}{r}* * * 0.0865 \\
(0.0202)\end{array}$ & $\begin{array}{r}* *-0.0984 \\
(0.0214)\end{array}$ & $\begin{array}{r}* * *-0.0783 \\
(0.0199)\end{array}$ & $\begin{array}{r}* * 0.0533 \\
(0.0231)\end{array}$ & $\begin{array}{r}* * * 0.0773 \\
(0.0199)\end{array}$ \\
\hline$g w 1_{m}$ & $\begin{array}{r}* * * 0.6115 \\
(0.1046)\end{array}$ & $\begin{array}{r}* * * 0.6660 \\
(0.0983)\end{array}$ & - & - & - & - & - \\
\hline$g w 2_{m}$ & $\begin{array}{r}{ }^{* *} 0.3143 \\
(0.1576)\end{array}$ & $\begin{array}{r}* * * 0.3983 \\
(0.1511)\end{array}$ & - & - & - & - & - \\
\hline$p w 1_{m}$ & $\begin{array}{r}0.0606 \\
(0.0999)\end{array}$ & - & $* * *-0.2264$ & - & - & - & - \\
\hline$p w 2_{m}$ & $\begin{array}{r}* * 0.2187 \\
(0.1127)\end{array}$ & - & $* * * 0.2963$ & - & - & - & - \\
\hline$e w 1_{m}$ & $\begin{array}{r}* *-0.1247 \\
(0.0709)\end{array}$ & - & - & $* * *-0.1730$ & - & - & - \\
\hline$e w 2_{m}$ & $\begin{array}{r}0.2310 \\
(0.0618)\end{array}$ & - & - & $* * * 0.2228$ & - & - & - \\
\hline$i w 1_{\mathrm{m}}$ & $\begin{array}{r}* * * 0.7570 \\
(0.0869)\end{array}$ & - & - & & $* * * 0.7930$ & - & - \\
\hline$i w 2_{\mathrm{m}}$ & $\begin{array}{r}0.2505 \\
(0.1595)\end{array}$ & - & - & - & 0.2172 & - & - \\
\hline$d w 1_{m}$ & $\begin{array}{r}0.2223 \\
(0.1895)\end{array}$ & - & - & - & - & 0.2651 & - \\
\hline$d w 2_{\mathrm{m}}$ & $\begin{array}{r}-0.0393 \\
(0.0470)\end{array}$ & - & - & - & - & -0.0863 & - \\
\hline $\operatorname{Ln}(C R D)$ & $\begin{array}{r}* * * 0.3571 \\
(0.0341)\end{array}$ & $\begin{array}{r}* * 0.3527 \\
(0.0340)\end{array}$ & $\begin{array}{r}* * * 0.3497 \\
(0.0342)\end{array}$ & $\begin{array}{r}* * * 0.3560 \\
(0.0341)\end{array}$ & $\begin{array}{r}* * * 0.3737 \\
(0.0340)\end{array}$ & $\begin{array}{r}* * * 0.3561 \\
(0.0341)\end{array}$ & $\begin{array}{r}* * * 0.3601 \\
(0.0341)\end{array}$ \\
\hline $\operatorname{grd}_{n}$ & $\begin{array}{r}* * * 3.7208 \\
(0.9158)\end{array}$ & $\begin{array}{r}* * * 4.3571 \\
(0.9486)\end{array}$ & - & - & - & - & - \\
\hline
\end{tabular}


Table 9 (continued)

\begin{tabular}{|c|c|c|c|c|c|c|c|}
\hline & Complete & Big & Public & Foreign & $\begin{array}{r}\text { Invest- } \\
\text { ment }\end{array}$ & $\begin{array}{l}\text { Develop- } \\
\text { ment }\end{array}$ & Basic \\
\hline pub $_{n}$ & $\begin{array}{r}2.6819 \\
(0.7127)\end{array}$ & - & $\begin{array}{r}* * * 3.0682 \\
(0.8103)\end{array}$ & - & - & - & . \\
\hline ext $_{n}$ & $\begin{array}{r}0.8616 \\
(0.2868)\end{array}$ & - & - & $\begin{array}{r}* * * 0.7384 \\
(0.2852)\end{array}$ & - & - & 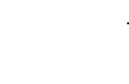 \\
\hline $\operatorname{inv}_{n}$ & $\begin{array}{r}2.9394 \\
(0.5761)\end{array}$ & - & - & - & $\begin{array}{r}* * * 2.9052 \\
(0.5753)\end{array}$ & - & 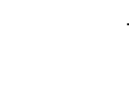 \\
\hline $\operatorname{des}_{n}$ & $\begin{array}{r}1.0808 \\
(1.3298)\end{array}$ & - & - & - & - & $\begin{array}{r}0.5894 \\
(1.6911)\end{array}$ & 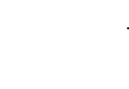 \\
\hline _cons & $\begin{array}{r}13.8941 \\
(0.2264)\end{array}$ & $\begin{array}{r}* * * 14.3544 \\
(0.2304)\end{array}$ & $\begin{array}{r}* * * 14.3322 \\
(0.2633)\end{array}$ & $\begin{array}{r}* * * 14.5982 \\
(0.2691)\end{array}$ & $\begin{array}{r}* * * 14.4909 \\
(0.2749)\end{array}$ & $\begin{array}{r}* * * 14.7199 \\
(0.2768)\end{array}$ & $\begin{array}{r}* * * 14.6621 \\
(0.2736)\end{array}$ \\
\hline $\mathrm{R}^{2}$ & 0.3049 & 0.2722 & 0.1447 & 0.0413 & 0.0548 & 0.0439 & 0.0486 \\
\hline $\mathrm{N}$ & 13144 & 13144 & 13144 & 13144 & 13144 & 13144 & 13144 \\
\hline
\end{tabular}

Notes: subscript $m$ represents the multiplicative dummy for the group of banks: large ( $g$ ), public (p), foreign (e), investment (i), and development (d). Subscript $n$ stands for level dummies for large banks (grd), public banks (pub), foreign banks (ext), investment banks (inv), and development banks (des). ***, ${ }^{* *}$, and ${ }^{*}$ - statistically significant at the 1,5 and $10 \%$ significance levels, respectively. $N$ is the number of observations. Robust standard errors are in parenthesis.

Assessing the $\mathrm{H}$-statistics for the complete regression in Table 10, only investment banks showed a positive coefficient and were statistically different from both 0 and 1 . This is representative of the monopolistic competition case. This finding is in line with the characteristics of these institutions, because investment banks have a smaller base of clients compared to commercial banks. But these special clients get high loan volumes and are charged lower interest rates when compared to clients of commercial banks. Investment banks do not accept deposits and have to appeal to banking credit market in order to finance loans. Basically, the reduced number of exclusive clients and the large volume of each credit operation encourage the competition among investment banks.

The other groups of banks present negative $\mathrm{H}$-statistics. According to Shaffer (1983), this automatically leaves them inside a noncompetitive market structure. Big banks reveal a reduced level of competition according to the H-statistics and greater market power than the other banks. This result is expected for the five major Brazilian banks, because they concentrate most of the deposits and are references in the credit market. 
Table $10 \mathrm{H}$-statistics for specific bank groups

\begin{tabular}{lrrrrr|r|r|r}
\hline & Complete & Big & Public & Foreign & $\begin{array}{r}\text { Invest- } \\
\text { ment }\end{array}$ & $\begin{array}{r}\text { Develop- } \\
\text { ment }\end{array}$ & Basic \\
\hline H_grd & $\begin{array}{r}-0.8066 \\
(0.1696)\end{array}$ & $\begin{array}{r}-0.6858 \\
(0.1603)\end{array}$ & - & - & - & - & - \\
\hline H_pub & -0.2302 & - & -0.3746 & - & - & - & - \\
& $(0.1293)$ & - & $(0.1221)$ & - & - & - & - \\
\hline H_ext & -0.4033 & - & - & -0.3997 & - & - & - \\
& $(0.0793)$ & - & - & $(0.0800)$ & - & - & - \\
\hline H_inv & 0.4979 & - & - & - & 0.4976 & - & - \\
& $(0.1386)$ & - & - & - & $(0.1389)$ & - & - \\
\hline H_des & -0.3265 & - & - & - & - & -0.2533 & - \\
& $(0.1942)$ & - & - & - & - & $(0.1997)$ & - \\
\hline H_geral & -0.5095 & -0.4181 & -0.4445 & -0.4495 & -0.5126 & -0.4321 & -0.4432 \\
& $(0.0337)$ & $(0.0299)$ & $(0.0301)$ & $(0.0307)$ & $(0.0297)$ & $(0.0305)$ & $(0.0294)$ \\
\hline
\end{tabular}

Note: The first column corresponds to the model with all dummies. The last column corresponds to the model without dummies. The remaining columns consider only one group at a time. Reported statistics are for the Wald test.

Compared to other studies for the Brazilian economy that apply the Panzar-Rosse method, Table 10 reports different results. Lucinda (2010) is methodologically closest to our approach but he finds an $\mathrm{H}$-statistics of 0.8 , much higher than the value of -0.51 reported in Table 10. Tabak, Gomes, and Medeiros Jr. (2015), despite finding an average value of 0.116 for the H-statistics, which is lower than Lucinda (2010), is still much higher than the value obtained here. Belaisch (2003) finds results even more discrepant, with the $\mathrm{H}$-statistics so high that in some cases it is not possible to reject the hypothesis of perfect competition. At the aggregate state level, Sanches et al. (2009) claim that the degree of banking competition is high, but not perfectly competitive, across the major Brazilian states.

Differently from previous works, based on the application of the Panzar-Rosse method and measuring the market power of the banking sector by the $\mathrm{H}$-statistics, we claim that Brazilian banks are not competitive. Using a framework that accounts for a multi-product banking firm, Barbosa et al. (2015) also estimated a negative value for the adjusted $\mathrm{H}$-statistic when controlling for multi-product banks. They found a positive bias in traditional estimates of competition and claimed that disregarding the multi- 
product structure of Brazilian banks might lead to underestimation of the market power of these banks.

\section{Concluding remarks}

The objective of this paper was to access the level of competition in the Brazilian banking market by applying the Panzar-Rosse model to a balanced panel data with 62 financial institutions from July 1994 to February 2012. Compared to other studies that indicated a market structure compatible with monopolistic competition, the results obtained here highlight the importance of incorporating in the analysis the seasonal adjustment of the data, the criticism by Bikker, Spierdijk, and Shaffer (2012) on the inclusion of scale variables and the normalization of administrative expenses per unit of credit granted.

The choice of the basic model followed Bikker, Spierdijk, and Shaffer (2012), who suggested the exclusion of any scale variable from the regression and any scale control among the variables. The sensitivity analysis about the effects of scale variables in the regression illustrates that the criticism is valid for the Brazilian case. In general, the model with a scale variable overestimates the $\mathrm{H}$-statistics, erroneously indicating the existence of some structure of competition in the banking sector.

Equally important to the accuracy of the results was the preliminary treatment of the seasonal effect observed in the financial variables. The presence of seasonality affected the estimated coefficients and the H-statistics. Studies that ignore the seasonal effect tend to incorrectly conclude that there are competitive structures in the Brazilian banking market, when there is considerable market power for the banks in general and other specific groups.

Comparisons among estimates with seasonally-adjusted and unadjusted data reveal the existence of a seasonal bias in the later results. This bias is characterized by producing statistical results which always indicate the existence of competitive structures, $H>0$, even when this is not true. The inclusion of a scale variable in the regressions was less impacting than the seasonal adjustment, but it was strong enough to change the degree of competition for some banks. The seasonal effect tends to overestimate the $\mathrm{H}$-statistics, leading to the false competitive result. The findings by 
Belaisch (2003), Araujo and Jorge Neto (2007), Lucinda (2010), and Tabak, Gomes, and Medeiros Jr. (2015) might exhibit the seasonal bias in addition to problems associated with the use of scale variables.

Our findings reveal that, in general, Brazilian banks are not competitive. The exceptions are investment banks, which have an $\mathrm{H}$-statistics compatible with a monopolistic competition market structure. The five biggest banks are not competitive and their market power is considerably higher than that of the other institutions. This might help to explain the high profitability and high interest rates practiced by banks in the Brazilian economy.

Public banks have lower market power than banks in general. However, these banks do not act as if they were in perfect competition. This is due to political interference in management decisions that public banks are frequently subject to, distancing them from the behavior of private institutions that seek profit maximization.

These findings differ from those of other studies for the Brazilian economy, including Belaish (2003), Araujo and Jorge Neto (2007), Lucinda (2010), and Tabak, Gomes, and Medeiros Jr (2015). We provided empirical evidence that the Brazilian banking sector does not operate under competition, contrary to the findings provided by those authors. Recently, Barbosa et al. (2015) also found evidence of high market power in the banking sector after taking into account the multi-product structure of the Brazilian banks. For further research, one should evaluate the efficiency of distinct seasonal adjustment methods applied to financial series, compute the Lerner Index, and extend the discussion on how the normalization of input prices might generate alternative ways of working with the PanzarRosse model.

\section{References}

ARAÚJO, L. A. D. D.; JORGE NETO, P. D. M.; PONCE, D. A. S. Competição e Concentração entre os Bancos Brasileiros. Revista Economia, v.7, n.3, p.561-586, 2006.

ARAÚJO, L. A. D. D.; JORGE NETO, P. D. M. Risco e competição bancária no Brasil. Revista Brasileira de Economia, v. 61, n. 2, p. 175-200, 2007.

BARBOSA, K.; ROCHA, B. P.; SALAZAR, F. Assessing competition in the banking industry: A multi-product approach. Journal of Banking and Finance, v. 50, p. 340-62, 2015.

BELAISCH, A. Do Brazilian banks compete? IMF Working Papers 03/113, 2003. 
BIKKER, J. A.; HAAF, K. Competition, concentration and their relationship: An empirical analysis of the banking industry. Journal of Banking and Finance, n. 26, p. 2191-2214, 2002.

BIKKER, J. A.; SHAFFER, S.; SPIERDIJK, L. Assessing competition with the Panzar-Rosse model: The role of scale, costs, and equilibrium. The Review of Economics and Statistics, MIT Press, vol. 94(4), p. 1025-1044, 2012.

BRESNAHAN, T. F. The oligopoly solution is identified. Economics Letters, n. 10, p. 87-92, 1982.

CHOI, I. Unit root tests for panel data. Journal of International Money and Finance, n. 20, p. 249-272, 2001.

HARRIS, R. D. F.; TZAVALIS., E. Inference for unit roots in dynamic panels where the time dimension is fixed. Journal of Econometrics, n. 91, p. 201-226, 1999.

IM, K. S.; PESARAN, M. H.; SHIN., Y. Testing for unit roots in heterogeneous panels. Journal of Econometrics, v. 115, p. 53-74, 2003.

LAU, L. J. On identifying the degree of competitiveness from industry price and output data. Economics Letters, n. 10, p. 93-99, 1982.

LEVIN, A.; LIN, C. F; CHU, C.-S. J. Unit root tests in panel data: asymptotic and finite-sample properties. Journal of Econometrics, v. 108, n. 1, p. 1-24, 2002.

LUCINDA, C. R. Competition in the Brazilian loan market: An empirical analysis. Estudos Econômicos, São Paulo, v. 40, p. 831-858, 2010.

NAKANE, M. I. A test of competition in Brazilian banking. Estudos Econômicos, n. 32, p. 203224, 2002.

PANZAR, J. N.; ROSSE, J. Testing for monopoly equilibrium. Journal of Industrial Economics, n. 35, p. 443-456, 1987.

SANCHES, F. M.; ROCHA, B. P.; SILVA, J. C. Estimating a Theoretical Model of State Banking Competition Using a Dynamic Panel: The Brazilian Case. Revista Brasileira de Economia, v. 63 , p. 23-34, 2009.

SHAFFER, S. The Rosse Panzar statistic and the Lerner index in the short run. Economics Letters, n. 11, p. 175-178, 1983.

TABAK, B. M.; GOMES, G. M. R.; MEDEIROS JÚNIOR, M. D. S. The impact of market power at bank level in risk-taking: The Brazilian case. International Review of Financial Analysis, v. 40, p. 154-165, 2015.

\section{About the authors}

José Angelo Divino - jangelo@pos.ucb.br

Universidade Católica de Brasília. Brasília, Distrito Federal.

Renan Said Silva - renansaiducb@hotmail.com

Universidade Católica de Brasília. Brasília, Distrito Federal.

The authors would like to thank participants in the XLI Meeting of the Brazilian Economic Association (ANPEC) for the helpful comments and suggestions and $\mathrm{CNPq}$ for financial support. All remaining errors are the authors' sole responsibility.

\section{About the article}

Submission received on October 21, 2015. Approved for publication on September 10, 2017. 